\title{
CAEP 2016 Academic Symposium: How to have an impact as an emergency medicine educator and scholar
}

\author{
Jason R. Frank, MD, MA(Ed)*; Warren J. Cheung, MD, MMEd*; Jonathan Sherbino, MD, MEd ${ }^{\dagger}$; \\ Robert Primavesi, MD ${ }^{\ddagger \S}$; Robert A. Woods, MD, MMEd"; Glen Bandiera, MD, MEd**; \\ Constance LeBlanc, MD, MAEd ${ }^{\dagger \dagger}$
}

\section{ABSTRACT}

Background: In a time of major medical education transformation, emergency medicine (EM) needs to nurture education scholars who will influence EM education practice. However, the essential ingredients to ensure a career with impact in EM education are not clear.

Objective: To describe how to prepare EM educators for a high-impact career.

Methods: The Canadian Association of Emergency Physicians (CAEP) Academic Section commissioned an "Education Impact" working group (IWG) to guide the creation of consensus recommendations from the EM community. EM educators from across Canada were initially recruited from the networks of the IWG members, and additional educators were recruited via snowball sampling. "High impact educators" were nominated by this network. The high impact educators were then interviewed using a structured question guide. These interviews were transcribed and coded for themes using qualitative methods. The process continued until no new themes were identified. Proposed themes and recommendations were presented to the EM community at the CAEP 2016 Academic Symposium. Feedback was then incorporated into a final set of recommendations.

Results: Fifty-five (71\%) of 77 of identified Canadian EM educators participated, and 170 names of high impact educators were submitted and ranked by frequency. The IWG achieved sufficiency of themes after nine interviews. Five recommendations were made: 1) EM educators can pursue a high impact career by leveraging either traditional or innovative career pathways; 2) EM educators starting their education careers should have multiple senior mentors; 3) Early-career EM educators should immerse themselves in their area of interest and cultivate a community of practice, not limited to EM; 4) Every academic EM department and EM teaching site should have access to an EM educator with protected time and recognition for their EM education scholarship; and 5) Educators at all stages should continuously compile an impact portfolio.

Conclusions: We describe a unique set of recommendations to develop educators who will influence EM, derived from a consensus from the EM community. EM leaders, educators, and aspiring educational scholars should consider how to implement this guide towards enhancing our specialty's educational mission.

\section{RÉSUMÉ}

Contexte: À une époque où l'enseignement de la médecine connaît des mutations importantes, la médecine d'urgence (MU) se doit de soutenir les chercheurs en enseignement qui influenceront la pratique de l'enseignement dans cette dernière discipline. Toutefois, on ne connaît très bien les ingrédients essentiels à une carrière influente dans l'enseignement de la MU.

Objectif: L'exercice visait à décrire la préparation des éducateurs en $\mathrm{MU}$ en vue d'une carrière influente.

Méthode: La section des affaires universitaires de I'Association canadienne des médecins d'urgence (ACMU) a formé un groupe de travail sur l' " influence en éducation " et l'a chargé de guider l'élaboration de recommandations consensuelles en s'appuyant sur la communauté en MU. Des éducateurs en MU de partout au Canada ont d'abord été recrutés à partir des réseaux des membres du groupe de travail, auxquels se sont joints d'autres éducateurs choisis à l'aide de la méthode du sondage en boule de neige. Les "éducateurs influents " ont été désignés par le réseau, puis rencontrés en entrevues menées à l'aide d'un guide de questions structuré. On a par la suite transcrit et codé les entrevues pour dégager les thèmes, à l'aide de méthodes qualitatives. Le processus s'est poursuivi jusqu'à ce qu'on ne puisse plus trouver de nouveau thème. Les thèmes proposés et les recommandations ont été présentés à la communauté en MU à l'occasion du

From the *Department of Emergency Medicine, University of Ottawa Faculty of Medicine, Ottawa, ON; †Division of Emergency Medicine, McMaster University, Hamilton, ON; ‡Department of Family Medicine and §Department of Pediatrics, McGill University, Montreal, QC; IDepartment of Emergency Medicine, University of Saskatchewan, Saskatoon, SK; **Division of Emergency Medicine, Department of Medicine, University of Toronto, Toronto, ON; and the ††Dalhousie University Faculty of Medicine, Halifax, NS.

Correspondence to: Dr. Warren Cheung, The Ottawa Hospital, 1053 Carling Avenue, Room 658, Ottawa, ON K1Y 4E9; Email: wcheung@toh.ca 
Symposium sur les affaires universitaires de I'ACMU 2016. Les rétroactions ont ensuite été intégrées au document de travail pour finalement former un ensemble définitif de recommandations.

Résultats: Sur 77 éducateurs repérés en MU au Canada, $55(71 \%)$ ont participé à l'exercice. Cent soixante-dix noms d'éducateurs influents ont été soumis, puis classés par ordre de fréquence. Le groupe de travail a atteint un plafond de thèmes après neuf entrevues. II s'est dégagé de l'exercice cinq recommandations : 1) les éducateurs en MU peuvent poursuivre une carrière influente en empruntant soit les voies classiques, soit des voies innovatrices du cheminement de carrière; 2) les éducateurs en $\mathrm{MU}$ qui commencent leur carrière dans l'enseignement devraient avoir plusieurs mentors d'expérience; 3) les éducateurs en $M U$ en début de carrière devraient s'investir dans leur domaine de prédilection et cultiver une communauté de praticiens, même en dehors de la $\mathrm{MU}$; 4) tous les départements de MU dans les universités et tous les lieux d'enseignement de la MU devraient avoir accès auprès d'un éducateur en $\mathrm{MU}$, disposer de périodes réservées et reconnaître les travaux de recherche en enseignement de la $\mathrm{MU}$; 5) les éducateurs devraient, à toutes les étapes, entretenir continuellement un portefeuille d'influence.

Conclusions: L'exercice a permis de dresser un ensemble unique de recommandations visant à former des éducateurs qui auront de l'influence en médecine d'urgence, ensemble consensuel établi à partir de la communauté en MU. Les meneurs en médecine d'urgence, les éducateurs et les futurs chercheurs en enseignement devraient se pencher sur la manière d'appliquer le guide afin de porter encore plus loin la mission éducative de notre spécialité.

Keywords: scholarship, impact, medical education

\section{INTRODUCTION}

Education scholarship is a critical activity for a rapidly expanding specialty like emergency medicine (EM). According to van Melle, "Education scholarship is an umbrella term which can encompass both research and innovation in health professions education."1 In an era of major change in the way that health professionals will be trained in Canada and worldwide, EM needs more education scholars who can innovate, research, and disseminate advances in education. ${ }^{2-5}$ However, what is unclear is how EM education scholars can achieve high impact careers that influence and advance the practice of EM in ways that ultimately have a positive effect on patient care.

The Canadian Association of Emergency Physicians (CAEP) Academic Section was created in 2013 with the vision to "promote high-quality emergency patient care by conducting world-leading education and research in emergency medicine (EM)." The three committees of the CAEP Academic Section take turns leading a symposium on education, ${ }^{6-8}$ research, ${ }^{9-12}$ or leadership at the CAEP annual conference to present their latest findings and recommendations. ${ }^{13-15}$ At CAEP 2016, the area of focus was education scholarship with the theme: "The Pathway to Success." The goal of the 2016 Academic Symposium on Education Scholarship was to provide pragmatic recommendations in three areas: 1) recommended training for those pursuing academic roles in EM education, 2) recommendations on how to make an impact in medical education, and 3) the specifics on how to publish in the area of education scholarship. In this paper, we describe the results of the consensus recommendations on how to have a high impact career in medical education.

\section{METHODOLOGY}

We created an "Education Impact" working group (IWG) to identify the essential career elements of recognized medical educators who have influenced and advanced medical education, regardless of the specialty. The seven-member working group was formed from education scholars representing both EM training streams and six medical schools from across Canada. They met by teleconference 10 times from September 2015 to July 2016. The IWG developed their consensus recommendations using a systematic approach that engaged the Canadian EM community. At the outset, the IWG conducted a literature review of education scholarship and adopted the van Melle definition. We then defined education impact as: a productive scholarly career recognized as having a significant and powerful influence on the practice of others.

Using the previous definitions, the IWG members then identified individuals involved in EM education scholarship from the 17 Canadian medical schools, with a final list of individuals reviewed for completeness by the full working group. Each person on this list was contacted with the same structured request to 1) name individuals whom they would call high impact medical educators (who were not required to be physicians or emergency physicians) and to 2) identify others involved in EM scholarship ("snowball sampling") who 


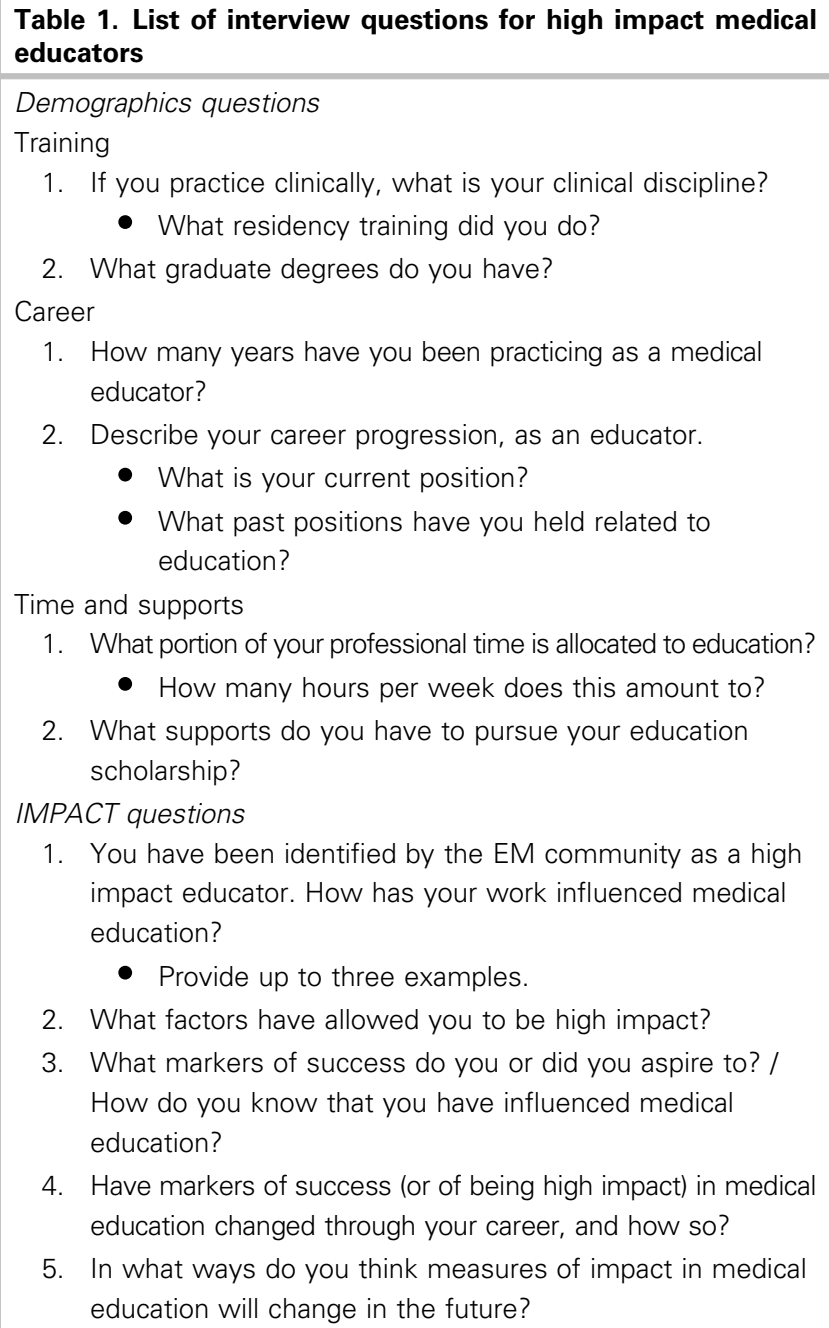

2. What graduate degrees do you have?

1. How many years have you been practicing as a medical educator?

2. Describe your career progression, as an educator.

- What is your current position?

- What past positions have you held related to education?

Time and supports

1. What portion of your professional time is allocated to education?

- How many hours per week does this amount to?

2. What supports do you have to pursue your education scholarship?

IMPACT questions

1. You have been identified by the EM community as a high impact educator. How has your work influenced medical education?

- Provide up to three examples.

2. What factors have allowed you to be high impact?

3. What markers of success do you or did you aspire to? / How do you know that you have influenced medical education?

4. Have markers of success (or of being high impact) in medical education changed through your career, and how so?

5. In what ways do you think measures of impact in medical education will change in the future?

could participate in the consensus process. All names for the high impact educator list were collected electronically and ranked by frequency. It was decided a priori that if the names of any of the IWG were put forth they would be excluded from the rank list. The top five individuals on the rank list were interviewed by IWG members using a standard interview script. Each interviewee was asked the same series of questions (Table 1), with which they were provided in advance of the interview. Following the initial five interviews, the transcripts were coded for themes using interpretive descriptive methods by two of the working group (JRF, WJC). ${ }^{16}$ Subsequently, the next highest ranked individual was interviewed, and this continued until sufficiency (absence of additional themes) was reached. All interviews were audio recorded, and field notes were taken.

\section{ANALYSIS}

Two independent authors (JRF, WJC) reviewed the audio recordings and field notes, and conducted an inductive analysis to identify emerging themes. These themes were presented to the full IWG for review. Themes that were felt to be similar were merged or grouped within broader themes. The themes were presented at the 2016 CAEP Academic Symposium to 90 attendees from the EM community, including practicing physicians, residents, medical students, and senior EM leaders. Participants self-selected based on their interest in the CAEP Academic Section and/or the topic. The attendees vetted the proposed themes for understanding and validity before working in small groups to provide recommendations around an assigned theme. These recommendations were then presented to the symposium attendees at-large for further discussion and refinement. At a follow-up teleconference, the themes and draft recommendations were refined by the IWG, and the recommendations were finalized and circulated to the Academic Section for final comments in August 2016. All feedback was incorporated into a final set of recommendations for the Canadian EM community.

\section{RESULTS}

Fifty-five (71\%) of 77 identified EM medical educators participated. In total, 170 names of high impact educators were submitted (ranging from 1 to as many as 11 nominations per person); 102 unique names were identified as medical educators with impact, and IWG members were removed. For the interviews, theme sufficiency was reached upon completion of the ninth interview. Seven broad themes were identified, and each included from three to nine subthemes (Table 2).

\section{RECOMMENDATIONS}

The IWG developed the following recommendations for EM educators who wish to have a career that influences and advances medical education, practice, and patient care:

\section{EM educators can pursue a high impact career by leveraging either traditional academic structures or innovative career pathways}

Two distinct career paths emerged from the consensus process. The first was labelled "traditional academic" 


\section{Table 2. Themes identified from high impact medical educators about their career path}

Theme Subtheme

1. There are two major career arcs for highly high impact educators.

2. Enablers of high impact

3. Multifaceted work-life integration

4. Motivations

5. The many faces of "impact" or success

6. Disruptive technology

7. Evolution of impact
1.1. Trailblazers within academe

1.2. Dissatisfied rebels

1.3. All seek to change the system.

2.1. Preparation

2.1.1. Identifying mentors and role models

2.1.2. Saying yes at key opportunities and capitalizing on them

2.1.3. Taking on increasing roles

2.1.4. Gaining credentials in medical education

2.2. Community

2.2.1. Establishing a network of expert colleagues and collaborators

2.2.2. Working with your community

2.3. Strategy

2.3.1. Focusing on a program of scholarship (traditional or otherwise) that is unique and influential

2.3.2. Carving out protected time

2.4. Resources

2.4.1. Accessing resources

2.4.2. Accessing institutional support

3.1. A passion: work is hobby and mission

3.2. Mix of professional work

3.3. Mix of funding

3.4. Entrepreneurial: working beyond what colleagues do

3.5. Trade-offs

4.1. Internal

4.1.1. Joy of endeavour (i.e., pleasure of teaching, researching, speaking, influencing, etc.)

4.2. External formal

4.2.1. Recognition (i.e., awards, invitations, promotions, etc.)

4.3. External informal

4.3.1. Uptake of work (used work for a case, etc.)

4.3.2. Triggering discussions in the community

5.1. Teaching generations of medical education

5.2. Mentoring other leaders

5.3. Use of traditional scholarship (e.g., publications, grants, awards)

5.4. Invitations to speak or consult

5.5. Uptake of work

5.6. Stimulating a discussion in a community

5.7. Changing practice

5.8. Worldwide network

5.9. Name associated with field or body of work

6.1. New tech has greater reach

6.2. Can bypass traditional structures

6.3. Perhaps greater influence

6.4. Sometimes demeaned by traditional structures

7.1. Shift from scholarly activities to scholarship

7.2. Greater recognition for education in university

7.3. New measures of scholarship (e.g., H-index, impact factor, citations)

7.4. Need new metrics for digital age

7.5. Need better measures of knowledge translation and uptake 
and involved a career focused on developing scholarly innovations, obtaining grants, conducting research, and disseminating via traditional print journals within the infrastructure of universities. High impact educators used these activities within academe as a platform to influence the practice of other educators and practitioners, and were recognized as important scholars. The second career pathway was labelled as "innovative" and was described as a way of having impact enabled by digital technology. In the field of medical education, digital platforms (e.g., social media) were perceived as a means of reaching a broader audience in a more timely fashion than traditional channels of disseminations (e.g., print journals). The use of these new technologies helped the high impact educators support the accelerated translation and uptake of their education innovations by bypassing traditional structures. ${ }^{17,18}$ Using the innovative pathway, they developed new organizations and digital platforms (e.g., https://www.aliem.com/ and https://www.emrap. org/) on which to innovate and widely disseminate their work. EM educators can use one or both of these career paths when deciding on their approach to having impact.

\section{EM educators starting their education careers should have multiple senior mentors}

All contributors identified the need and benefits of effective mentorship for those embarking on a career of scholarship. Mentors enable development of scholars, break down barriers to career advancement, enhance networking, and can coach junior scholars to be more high impact. It was emphasized that no single mentor can meet all of these needs, hence the "personal board of directors" concept to support aspiring scholars via nurturing by several leaders. ${ }^{1,19}$ The nine interviewees described actively engaging in the medical education community as an essential first-step to identifying potential mentors. They described mentorships as being developed over time while working closely with more senior educators. Therefore, aspiring EM educators should seek opportunities for scholarly collaboration with seasoned educators within their focused area of interest. As soon as a mentoring relationship is established, EM educators can access their primary mentor's broad network of colleagues and collaborators to identify additional mentors.

\section{Early-career EM educators should immerse themselves in their area of interest and cultivate a community of practice, not limited to EM}

Contributors to the consensus process highlighted the need for focus and immersion in the field of medical education for EM. The interviewed high impact educators expressed a passion for their contributions to the medical community, and each was motivated to reach beyond the typical expectations of his or her field. Aspiring EM educators need to find an area of focused interest within medical education (their "niche"), equip themselves with the training and credentialing needed to effectively engage within the community of practice, and find their unique way of contributing. Initially chosen niches are often not in the exact domain where the educator will ultimately establish high impact, but the journey of each of these interests often leads to a deeper discovery of how to influence and advance medical education. Furthermore, developing a network of expert colleagues and collaborators, as well as working with the medical education community were viewed as essential. This concept invokes parallels with other human endeavours that pursue elite performance (e.g., music, sport, chess) in that dedication and collaborations are required to truly achieve a level that is high impact. $^{20}$

\section{Every academic EM department and EM teaching site should have access to an EM educator with protected time and recognition for their EM education scholarship}

EM, as a rapidly growing specialty in an era of dramatic change in medical training, urgently requires a cadre of expert medical educators. The IWG recommends that every Canadian academic EM program recruit and support one or more dedicated clinician educators. ${ }^{21}$ To enable our young specialty to be a leader and innovator in medical education, we need high impact educators to be a resource to every major EM organization.

\section{Educators at all stages should continuously compile an impact portfolio}

Contributors emphasized the need for all scholars to document their impact on an ongoing basis. More than a traditional portfolio for academic promotion (documenting publications, abstracts, and grants), the IWG identified the need for an "impact portfolio" that 
documented other measures of influence. This larger body of work can include such elements as evidence of invited presentations, consultations, awards and honours, mentees and graduate students, uptake of innovations, stimulated discourses in a community, changes to practice, or a named field.

\section{CONCLUSION}

The concept of high impact educational scholarship and how to achieve it was identified as a priority for the EM community. In this paper, we describe a unique set of recommendations on the essential ingredients for developing a cadre of scholarly EM educators recognized as influential and practice-changing innovators. EM leaders, educators, and aspiring educational scholars should consider how to implement this guide to enhance our specialty's educational mission.

Acknowledgements: The background and themes of this article were presented at the 2016 Academic Symposium on Education Scholarship in Emergency Medicine on 4 June 2016 at CAEP 2016 in Québec City. The authors thank the high impact educators for providing their time and expertise (in alphabetical order): Georges Bordage, Patrick Croskerry, Kevin Eva, Mel Herbert, Brian Hodges, Michelle Lin, Lorelei Lingard, Ivan Silver, and Scott Weingart. We also thank all of the many dedicated EM educators within our community who provided names of those educators who have made an impact on them. We extend our thanks to Kelly Wyatt and Jennifer D. Artz at the CAEP office.

Competing interests: None declared.

\section{REFERENCES}

1. Van Melle E, Lockyer J, Curran V, et al. Toward a common understanding: supporting and promoting education scholarship for medical school faculty. Med Educ 2014;48(12):1190-200.

2. Kohn LT (ed.). Institute of Medicine. Academic bealth centers: leading change in the 21st century. Washington, DC: The National Academies Press; 2004.

3. Brimacombe GG and members of the Academic Health Science Center Task Force. Three missions, one future-: optimizing the performance of Canada's Academic Health Sciences Centres. Association of Canadian Academic Healthcare Organizations; 2010.

4. Kanter SL. Toward better descriptions of innovations. Acad Med 2008;83(8):703-4.

5. Frank JR, Snell LS, Cate OT, et al. Competency-based medical education: theory to practice. Med Teach 2010;32(8): 638-45.
6. Sherbino J, Van Melle E, Bandiera G, et al. Education scholarship in emergency medicine part 1: innovating and improving teaching and learning. CFEM 2014;16(Suppl 1): S1-5.

7. Bhanji F, Cheng A, Frank JR, et al. Education scholarship in emergency medicine part 3: a "how-to" guide. CFEM 2014;16 (Suppl 1):S13-8.

8. Bandiera G, Leblanc C, Regehr G, et al. Education scholarship in emergency medicine part 2: supporting and developing scholars. CFEM 2014;16(Suppl 1):S6-12.

9. Stiell IG, Artz JD, Perry J, et al. Executive summary of the CAEP 2014 Academic Symposium: how to make research succeed in your department. CFEM 2015;17(3): 328-33.

10. Vaillancourt C, Rowe BH, Artz JD, et al. CAEP 2014 Academic Symposium: how to make research succeed in your department: how to fund your research program. CFEM 2015;17(4):453-61.

11. Calder LA, Abu-Laban RB, Artz JD, et al. CAEP 2014 Academic Symposium: how to make research succeed in your department: promoting excellence in Canadian emergency medicine resident research. CFEM 2015;17(5): 591-9.

12. Perry JJ, Snider CE, Artz JD, et al. CAEP 2014 Academic Symposium: how to make research succeed in your emergency department: how to develop and train career researchers in emergency medicine. CFEM 2105;17(3): 334-43.

13. Lang ES, Artz JD, Wilkie RD, et al. CAEP 2015 Academic Symposium: current state and recommendations to achieve adequate and sustainable funding for emergency medicine academic units. CFEM 2016;18(Suppl 1):S10-17.

14. Sinclair D, Worthington JR, Joubert G, et al. CAEP 2015 Academic Symposium: leadership within the emergency medicine academic community and beyond. CFEM 2016;18 (Suppl 1):S1-9.

15. Petrie D, Chopra A, Chochinov A, et al. CAEP 2015 Academic Symposium: recommendations for university governance and administration for emergency medicine. C $\mathcal{F} E M$ 2016;18(Suppl 1):S18-25.

16. Thorne S, Reimer Kirkham S, O'Flynn-Magee K. The analytic challenge in interpretive description. Int 7 Qual Methods 2004;3(1):1-21.

17. Sherbino J. The social media summit in health professions education. Postgrad Med 7 2015;91(1080):542-3.

18. Sherbino J, Arora VM, Van Melle E, et al. Criteria for social media-based scholarship in health professions education. Postgrad Med 7 2015;91(1080):551-5.

19. Humphrey HJ. Mentoring in academic medicine. Philadelphia, PA: ACP Press; 2010.

20. Ericsson KA, Charness N, Feltovich PJ, et al. The Cambridge bandbook of expertise and expert performance. 1st ed. New York: Cambridge University Press; 2006.

21. Sherbino J, Frank JR, Snell L. Defining the key roles and competencies of the clinician-educator of the 21 st century: a national mixed-methods study. Acad Med 2014;89(5): 783-9. 